\title{
Intellectual freedom principles for academic libraries: Third draft
}

\author{
Prepared by the ACRL Intellectual Freedom Committee
}

1 The privacy of library users is sacrosanct. Policies should be in place that maintain confidentiality of library borrowing records and of other information relating to personal use of library information. These policies should embrace books borrowed, reserve items used, areas of research activity, and databases consulted. The location of some computer workstations should be planned to provide a degree of privacy.

2 The development of library collections should transcend the personal values of the selector. In the interests of research and learning, it is appropriate that collections contain materials representing a variety of perspectives on subjects that may be considered controversial.

3 Preservation and replacement efforts 3 should ensure that the balance in library materials is maintained and that controversial materials are not lost to the collections through theft, loss, or normal wear and tear. Staff should be alert to efforts by special interest groups to bias a collection though systematic theft or mutilation.

4 Licensing agreements are the only legititabases. These agreements should not be in conflict with the Library Bill of Rights and should maximize access.

5 Only unfiltered access to the Internet should be offered in an academic library. Filtering devices are a contradiction of the academic library mission to further research and learning through exposure to the broadest possible range of information resources.
6 Freedom of information and of expreshibits and reflected in library policy documents as an essential American value.

7 Library meeting rooms and research carrels should be available to all library users regardless of research being pursued or subject being discussed. Any restrictions made necessary because of limited availability should be based on such factors as academic status and need for the space rather than on content of research or discussion.

Q Whenever possible, library services should be available without charge in order not to discourage inquiry. Where charges are essential, a free or low-cost alternative (e.g., downloading to disc rather than printing) should be available when possible.

C) A service culture should be promoted that affords equal access to information for all in the college or university community with no discrimination on the basis of race, values, sex, sexual orientation, cultural or ethnic background, religious beliefs, or views.

10 A procedure ensuring due process should be in place to deal with requests by those within and outside the college or university community for removal of library resources, exhibits, or services.

11 It is recommended that this statement of principle be endorsed by appropriate institutional governing bodies, including the faculty senate. 


\section{Developing the statement}

A strong intellectual freedom perspective is critical to the development of academic library collections and services that dispassionately meet the education and research needs of a college or university community. The general principles set forth in the Library Bill of Rights form an indispensable framework for building collections, services, and policies that serve the entire academic community. The purpose of this statement is to provide an interpretation of general intellectual freedom principles in an academic library setting and, in the process, raise consciousness of the intellectual freedom context within which academic librarians work.

ACRL's Intellectual Freedom Committee (IFC) developed two preliminary drafts of this document prior to ALA's 1999 Midwinter Meeting. At its January 30 meeting in Philadelphia, the committee adopted revi- sions that will serve as the basis for review by ACRL membership.

Part of the ACRL/IFC program at the 1999 ALA Annual Conference in New Orleans will be allocated to an open hearing on this statement. The program is scheduled for Monday, June 28, 9:30-11 a.m. Prior to the hearing. Steve Herb, chair of ALA's IFC and an academic librarian, will give a presentation entitled, "Freedom, Privacy, and the Internet: an Academic Library Primer."

Members of the IFC are Laurence Miller, chair; Susan Brynteson; Jack Forman; Charlotte Hess; Keith W. Russell; Marty Stilwell; Karen Bacsanyi, intern; Jennifer S. Burr, intern.

Readers are invited to send comments and suggested revisions to Laurence Miller, chair of the ACRL Intellectual Freedom Committee, e-mail: MillerL@fiu.edu or via fax at (305) 348-3408.
("And the winners. . . cont. from page 469)

\section{Law and Political Science (LPSS)}

Vice-Chair/Chair-Elect: Janice S. Lewis (54);

Lisa R. Stimatz (53).

Member-at-Large (2-year term): Madison

Mosely (60); Barbara P. Norelli (47).

Secretary (2-year term): Gabrielle M. Carr

(94); Write-In Candidate (3).

\section{Rare Books and Manuscripts (RBMS)}

Vice-Chair/Chair-Elect: Mark G. Dimunation

(195); Robert L. Maxwell (80).

Member-at-Large (3-year term): Jean w.

Ashton (137); Peggy E. Daub (126)

Secretary (2-year term): Thomas L. Amos

(141); D. Bruce Whiteman (116).

\section{Science and Technology (STS)}

Vice-Chair/Chair-Elect: Julie M. Hurd (163); Julia M. Gelfand (116).

Secretary/Member-at-Large (3-year term): Amy W. Shannon (145); Kathleen A. C. Fleming (114).

\section{Slavic and East European (SEES)}

Vice-Chair/Chair-Elect: Mieczyslaw (Mischa)

Buczkowski (27); Grazyna Slanda (20).
Member-at-Large (3-year term): Diana Greene (27); Maria Krystyna Borysiewicz (21).

\section{University Libraries (ULS)}

Vice-Chair/Chair-Elect: Elaine K. Didier (513); James J. Kopp (398)

Secretary (2-year term): John A. Lehner (420); Marc Meola (395).

Member-at-Large (3-year term, 2 to be elected): Ilene F. Rockman (580); Jeanne G.Sohn (538); Charles Wilt (313); Write-In-Candidate (8).

\section{Western European Specialists (WESS)}

Vice-Chair/Chair-Elect: Jeffrey Garrett (60);

Marje Schuetze-Coburn (45).

Secretary (1-year term): Kathleen Hunter

Rutter (60); Marianna McKim (44).

Member-at-Large (1-year term): Katalin

Radics (55); Laura Dale Bischof (50).

\section{Women's Studies (WSS)}

Vice-Chair/Chair-Elect: Theresa A. Tobin

(67); Emily S. Silverman (54).

Secretary (1-year term): Sandra A. River

(68); Charlene E. Hovatter (47).

Member-at-Large (2-year term): Dolores

Fidishun (61); May Montaser Jafari (56). 


\section{APA Books}

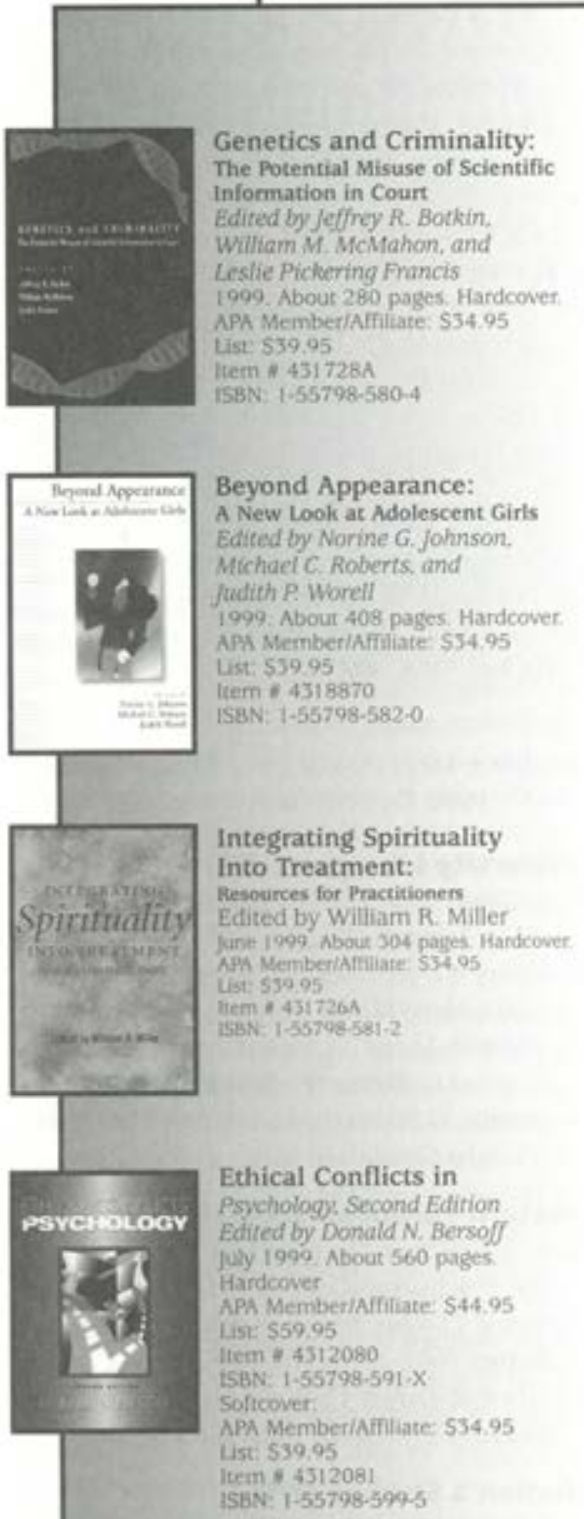

Beyond Talk Therapy:

Using Movement and Expressive Techniques in Clinical Practice

Edited by Daniel f. Wiener 1999. About 304 parges. Hardcover

APA Member/Affiliate: 534.95 List: $\$ 39.95$ Item in 451618 A ISBN: $1.55798-585-5$

Learning Through Children's Eyes:

Social Constructivism and the Desire to Learn Penny Oldfather and Jane West with Jernifer White and jull Wilmarth June 1999. About 120 pages

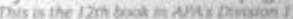

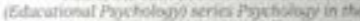

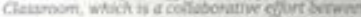

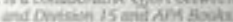
APA MemberlAfritiate 8 List $\$ 1705$ Item i $431619 \mathrm{~A}$ SBN: 1.55798 .587 .1

Working it Out: Using Exercise in Psychotherapy Kate $\mathrm{A}$ Hars

July 1999. About 350 pages Handcover

APA Member/Afiliate. $\$ 54,95$ List $\$ 399$ Item $* 431622 \mathrm{~A}$ ISBN: $1-55798.592 .8$
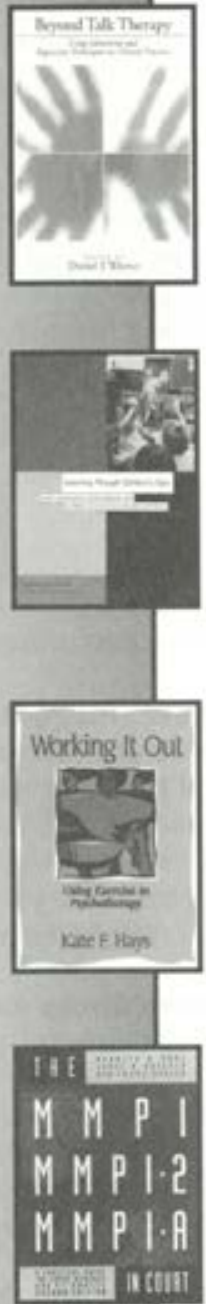

The MMPI, MMPI-2, and MMPI-A in Court:

A Practical Guide for Expert Witnesses and Artorneys. Second Edition Kenneth S. Pope, James N. Butcher and lonce Seclen

July 1999. About 550 pages Hardcower

APA MemberlAmiliare: $\$ 4906$ List $\$ 69.95$ Item $431729 A$ ISBN: 1-55798-590-1 


\title{
ON AUDIOCASSETTE TAPES
}

\section{Association of College and Research Libraries 9th National Conference}

\author{
April 8 - 11, 1999
}

Detroit, MI

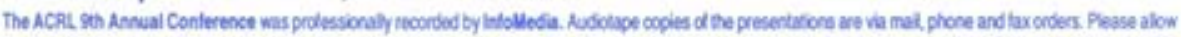

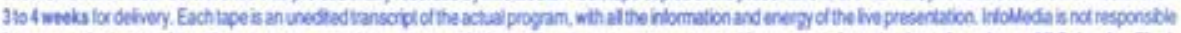

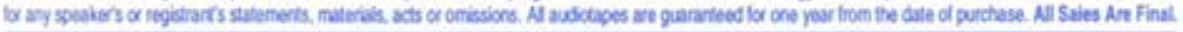

PROGRAM NUMBER MS133 - Please Check The Box By The Session(s) You Wish To Purchase

口MS133-1 An Open Forum on Copyright/Fair Use

$\$ 9.00 \quad$ P. Schroeder, J. Neal

MS133-2 Conference-within-a-Conference,

$\$ 9.00 \quad$ E. Gordon Gee, N. Lane, L. Roth, A. Jenkins

MS133-5 A Successful Partnership Library,

$\$ 9.00 \quad$ P. Blome, N. Lund; Changing Collaborations to Deliver Information in New Ways: Lessons Learned in the Illinois Digital Library Initiative Project T. Cole, W. Mischo

MS133-6 Faculty Use of Electronic Journals at $\$ 9.00$ Research Institutions, D. Lenares; Implementing E-Reserves: Homegrown vs. Turnkey, S. Nackerud

MS133-7 Full Text Databases Coverage of Core $\$ 9.00$ Journal Titles, J. A. Cart, A. Wolle; Expansion of Electronic Resources: Superhighway to Campus Visibility F. Davis

MS133-8 Racing to Keep Up With an Electronic $\$ 9.00 \quad$ FDLP: Its Effect on Professional Relationships of Academic Government Document Librarians, A. Roselle

MS133-9 Building a Campus Presence One $\$ 9.00$ Page at a Time: Web Strategies for the Small College Library, N. Dewald; Harvesting Hyperspace: Developing Technological Solutions to Internet Resources Discovery and Description G. McClellan

DS133-11 "Why Are You Using the Library?" or, $\$ 9.00$ The Real Goals of Library Research in the Academic Curriculum, E. Hammond; Creating Our Roles as Reference Librarians of the Future: Choice or Fate?, S. Szasz Palmer $\square$ MS133-12 Learning Communities, Adult Learners, $\$ 9.00$ and Instructional Teams at IUPUI, M. Jafari; The Librarian as Mediator: A Significant Change in the Educational Role of Librarians, D. Roe, D. Moody

MS133-13 Factors that Influence Online Database $\$ 9.00 \quad$ Use C. Tenopir, The UCSC Net Trail D. Murphy, A. Hubble

MS133-14 The Changing Nature of Higher $\$ 9.00 \quad$ Education, M. Pacheco

MS133-15 Collaboration in Designing Libraries to $\$ 9.00 \quad$ Meet the Changing Priorities of Academic Institutions in the 21st Century, G. Thompson, J. Lucker, W. Wickerham, T. Fu

MS133-17 Document Delivery in a Consortial $\$ 9.00$ Environment, M. Couts, P. Thibodeau, P. Mullin, K. Brown

DMS133-18 Introduction to island Theory: Chaos $\$ 9.00$ and the Evolvoing Library, C. Gilson, E. Brow, P. Gilson

MS133-19 Extending the Services of the $\$ 9.00 \quad$ University Libraries: The College Librarian Programs at Virginia Tech and Western Washington Universities, J. Schillie, M. Mernill, V. Young, J. Armstron, P. Piper

MS133-20 SPARC - Creating Solutions through $\$ 9.00$ Partnerships, R. Johnson, M. Case

MS133-21 The Brass Tacks of Information $\$ 9.00$ Literacy, D. Ward, P. Beavers, J. Nichols

\section{ORDER TODAY}


DS133-22 Using Digital Images on Campus:

$\$ 9.00$ Lessons from the Meseum Educa. tional Site Licensing Projectand its Descendants, H. Besser, B. Sandore, C. Stephenson

MS133.23 The New Genres of Scholarly

$\$ 9.00 \quad$ Communications and the Role of the Research Library, C. Lynch

MS133-24 Aligning Library Performance $\$ 9.00 \quad$ Measures with Institutional Outcomes and Outputs: A Case Study, D. Masters C. S. Hall, J. Ganson, L. Madden,

B. Gratch Lindauer

MS133-25 An Integrated Approach to Supporting $\$ 9.00$ Distance Education, L. Rein, J.Estrada, E. Eliceiri, K. Gaynor

MS133-26 The Development Teaching Portlolio $\$ 9.00$ for Librarians, N. Trejo, A. Lally, D. Howe-Noyes

MS133-27 Electronic Epiphanies: Constructing $\$ 9.00 \quad$ Criteria for Timely Evaluation of Electronic Journals, L. Crain, K. Hindes, A. Kenney, R. Bouchard-Hall

MS133-29 Redefining the Reference Environ$\$ 9.00$ ment: Racing Toward Tomorrow J. Richardson, M. Saxton, S. Cottman

MS133-30 The Cutting Edge: Services to Under$\$ 9.00 \quad$ graduates at Undergraduate Libraries. D. Taylor, R. DeDonato, J. Mckinstry. A. Sprunger, L. Ter Harr

MS133-31 The Bleeding Edge of Access to Full$\$ 9.00$ Text Electronic Information: Three Case Studies in Science and Technology, B. Reinhart, D. Atkins, F. Shrode, T. Dowling, P. Kreitz

MS133-32 (Digital) Libraries Support (Distributed) $\$ 9.00 \quad$ Education, G. McMillan

MS133-33 The ACRL Legislative/Public Policy $\$ 9.00 \quad$ Initiative Government Relations Committee, C. Gray, L. Bradley, A. Eisgrau, F. Weingarten

MS133-34 Developing Digital Products in Special $\$ 9.00$ Collections: Practices and Policies P. Daub, L. Browar, T. Hickerson, A. Cornell
MS133-35 Finding Our Voices: Effective $\$ 9.00 \quad$ Communication in the Changing Library, R. Wagner, S. Myers M. Warmkessel

MS133-36 Multiple Intelligences for Diverse $\$ 9.00$ Library Learners, K. Holmes

MS133-37 Taking Care of Business: Collaborat$\$ 9.00$ ing with Faculty to Create an Information Literacy Course for Undergraduate Business Students, L. Berendt, R. Benton

MS133-38 The Web as a Teaching Tool to $\$ 9.00$ Develop Information Literacy, A. Scott Ricker, H. Blakmer, J. Kelly A. Level

MS133-39 The User is the Expert: Experiences at $\$ 9.00$ Three Universities Using Usability Studies to Inform Gateway and Tutorial Web Designs, R. Dickstein, J. Veldot, A. Loomis, M. Prasse

MS133-40 Whose Job is It Anyway? Educating $\$ 9.00 \quad$ Academic Librarians for the 21st Century, C. Sheehy, B. Bengtson, P. Dalrymple, L. Howath

DMS133-41 Academic Publishing: Networks and $\$ 9.00 \quad$ Prices, M. Getz

- MS133-42 Electronic-Only Journals in the $\$ 9.00 \quad$ Sciences: Challenges and Solutions M. Leach, T. Kavanaugh, D. Solbrig. M. Blake

JMS133-43 Going the Distance: Library Services $\$ 9.00$ to a Global Community, S. Maret, E. Yang, G. Thomton, W. Meloy, J. Caspers

DMS133-45 IIL: Institute for Information Literacy $\$ 9.00 \quad$ Institute for Information Literacy Program, T. Kirk, M. Petrowski, C. Oberman, J. Todaro

MS133-46 Partnering for Outreach: Developing $\$ 9.00$ Programs for K-12 Schools, J. Nichois. L. Cousineau, D. Ferriero, L. Yesson

MS133-47 The Future of Library Research, $\$ 9.00$ M. Seadle L. Rockman, P. Hemon, D. Riggs

DMS133-48 National Learning Infra Structure $\$ 9.00$ Initiative, C. Barone, S. Hogan 
CMS133-49 United We Stand - Divided We Fail?: $\$ 9.00$

Combining Reference, Information, and Circulation Functions to Improve Services to Users, V. Steel, D. Helman, M. Finigan, L. Horowitz

MS133-50 Shifting Gears: A University President's $\$ 9.00$ View, B. Wilson

MS133-52 Remote Control: Creating a Technol$\$ 9.00$ ogy-Centered Library in Rural Alaska, A. Dufty; QUEST: A Collaborative Approach to Information Literacy S. Markley, M. Stein

MS133-53 Constructing the Library Starter Kit:

$\$ 9.00 \quad$ Developing New Technologies for Library Instruction, D. Murphy; Quality Undergraduate Education in a Research University - The Role of Information Literacy, A. Schnaftner, L. Stebbins, S. Wyman

MS133-54 Snowbird Leadership Institute: A

$\$ 9.00 \quad$ Survey of the Implications for Leadership in the Profession T. Neely, M. Winston

MS133-55 Role Call - What are Library Students $\$ 9.00 \quad$ Training for and What Will They Be Doing?, P. Coen-Pesch, E. Embser

MS133-56 Students Versus the Research Paper: $\$ 9.00 \quad$ What Can We Learn?, B. Valentine: Revelry, Revelation, or Research: What Are Students Really Doing on the Internet?, R. Wison

MS133-57 Getting It Right: Outcome-oriented $\$ 9.00 \quad$ Redesign of a Service Program in a Team-based Management Environment C. Palmer, S. Leung; Extinguishing Slow Fires: Cooperative Preservation Efforts, B. Baird, B. Schatiner

MS133-58 The Classroom vs. the Web:

$\$ 9.00 \quad$ Comparing Two Ways to Teach Webbased Resources, E. Bums

MS133-59 New Forms of Distance Education: $\$ 9.00 \quad$ Opportunities for Students, Threats to Institutions, L. Estabrook

MS133-61 Getting What You Want for Your $\$ 9.00$ Library! C. Beard, M. Crist, J. Stone Abramson
MS133-62 Libraries, Vendors, and Publishers: $\$ 9.00 \quad$ Changing Expectations, Changing Parnerships in a Networked Environment, C. Kern-Simirenko, J. Horrell, T. Bacher, E. Davis

MS133-63 Managing Technology in the Small

$\$ 9.00$ Academic Library, R. Gulstad,

P. McKirdy, B. Nedderman, P. Jenkins

MS133-64 Outwitting Cost Constraints: An $\$ 9.00$ Innovative Partnership Between Three Academic Institutions and the Rochester Public Library, P. Genovese. R. Madan, R. Milion

MS133-65 Teach My Class the Internet: Interenet $\$ 9.00 \quad$ Competencies for Undergraduate General Education Curriculum, P. Day, L. Janicke Hinchlitte, V. Schwartz, J. George

MS133-66 Distance Learning/Connected Learning $\$ 9.00$ for Information Literacy: An Instruction Section Assessment of Critical Issues and Section Efforts, N. Dewald, A. Booth, C. Levine, A. Scholz-Crane

MS133-67 Tune-Up for Optimum Reference $\$ 9.00 \quad$ Performance: Assessing Service Using WOREP, C. Radclitt, B. Schloman, M, DuMont, M. Havener

MS133-68 Scholarly Roles and Rewards for $\$ 9.00 \quad$ Librarians: Applying Ernest Boyer's "Scholarship Reconsidered", B. Park, W. B. Mitchell, M. Reichell, J. Ivan Legg

MS133-69 Directly to the Source: Will Academic $\$ 9.00 \quad$ Libraries Become Wholesalers of Information?, S. Anderson; Partnering for the Future: Integrating Traditional Interlibrary Lending and Commercial Document Delivery Into a Seamless Service, C. Kochan, D. Lee, R. Murdoch

MS133-70 Training ITAs: A Program for Student $\$ 9.00$ Information Technology Assistants, E. Engeldinger, A. Quick; First-Year Learning Communities: Redifing the Educational Roles of Academic Librarians, T. Taylor, T. Stamatoplos

MS133-71 Bringing LOGIC to Local Government $\$ 9.00$ Information: A Multi-type Partnership to Organize Local Governement Intormation, J. Horn, S. Leung; Intercepting Departmental Fumbles and Running with the Ball, D. Odom, A. Strout-Dapaz 
TMS133-72 Use of the Scenario Approach for $\$ 9.00$ Achieving Sustainable Development in Academic Libraries, S. Bell; The Improvisational Nature of the Change Process, F. Chu

IMS133-73 Designing for Wowl: The Optimal $\$ 9.00$ Information Gateway, K. Calhoun, Z. Koltay; Unified Information Access for the 21st Century, G. Smith, M. Pollard, Jt.

MS133-74 Assessment Outside of the Box: The $\$ 9.00 \quad$ Need for Focused Study of Information Seekers in a Changing Environment J. Burke, S. Harmony; Library Program Assessment, T. Kirk

MS133-75 In Search of Services: Analyzing the $\$ 9.00 \quad$ Findability of Links on CIC University Libraries' Web Pages, B. Dewey, That's My Bailiwick, P. Soderdahl, C. Hughes
MS133-76 Thinking Style Preferences Among

$\$ 9.00$ Academic Librarians, L. Golian; The Changing Nature of Work in Academic Libraries, B. Lynch, K. Robles Smith

MS133-77 Web-Based OPACs: A Leap of Faith? $\$ 9.00 \quad$ N. Medeiros, J. Beattie, C. Wu; Strategic Positioning and the Building Project: Penn State Harrisburg's Library of the Future, H. Shill

MS133-78 KEYNOTE: Reclaiming What We Own: $\$ 9.00 \quad$ Expanding Competition in Scholarly Publishing, M. Rosenzweig

MS133-79 Scenarios Wrap-up $\$ 9.00$

BUY 6 TAPES RECEIVE THE TTH FREE!

Purchase 12 Tape Vinyl Storage Album for $\$ 3.00$ or $\$ 5.00$ without purchase of cassette

FOR FASTER SERVICE

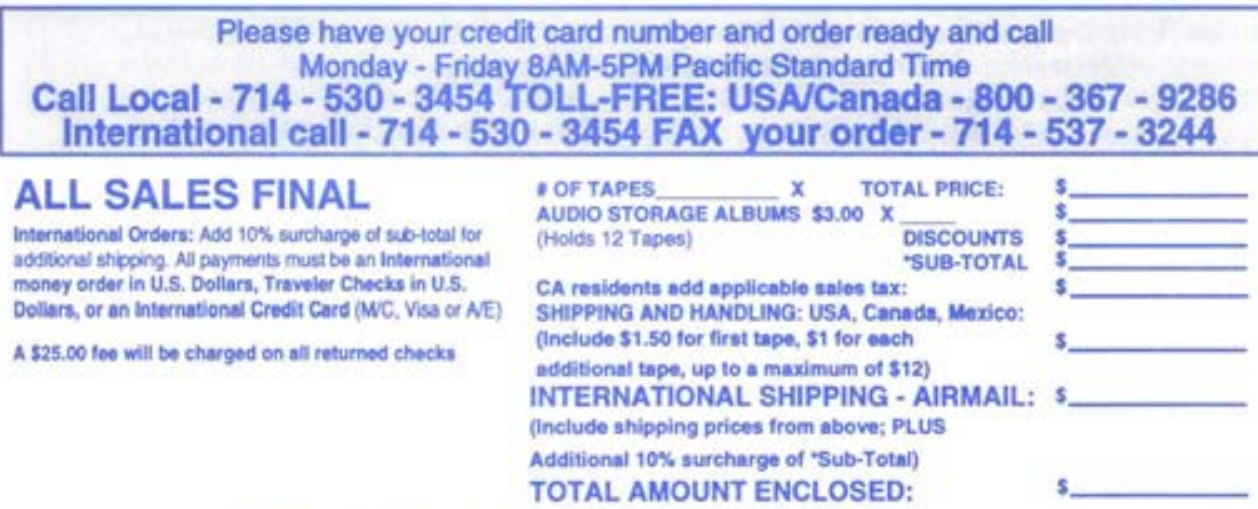

CHARGE TO: $\square$ M.C. $\square$ VISA $\square$ AVE $\square$ DISCOVER $\square$ My Check is Enclosed ACCT. \#_ Expires

Signature

Day Time Phone \# ( ) -

Name

Address

City/State/Zip

Please Check: $\square$ coMMERCIAL ADDRESS $\square$ RESIDENTIAL ADDRESS Infolledia

12800 Garden Grove Blvd. Suite F Garden Grove, CA 92843 (714) 530-3454 